\title{
Hydrogeochemical characterization of groundwater from semiarid region of western India for drinking and agricultural purposes with special reference to water quality index and potential health risks assessment
}

\author{
Huzefa Shaikh ${ }^{1} \cdot$ Himanshu Gaikwad $^{1} \cdot$ Ajaykumar Kadam $^{2}\left(D_{0} \cdot\right.$ Bhavana Umrikar $^{1}$
}

Received: 15 April 2020 / Accepted: 24 July 2020 / Published online: 7 August 2020

(c) The Author(s) 2020

\begin{abstract}
Increase in demand for water for domestic, agricultural and industrial needs has led to overexploitation as well as contamination; hence, it is unremittingly important to monitor and maintain the health of waters. In view of this, a study was carried out wherein a total of 57 groundwater samples from Upper Bhima Basin of western India were collected and analysed for understanding the drinking and agricultural suitability with special reference to water quality index and potential health risks assessment. Analysed physicochemical parameters indicated that the groundwater quality is not suitable in most of the villages for drinking and agricultural purposes. However, $\mathrm{pH}, \mathrm{TDS}, \mathrm{HCO}_{3}{ }^{-}, \mathrm{SO}_{4}{ }^{2-}, \mathrm{Cl}^{-}$and $\mathrm{F}^{-}$parameters were below the permissible limit; conversely, $\mathrm{Ca}^{2+}, \mathrm{Na}^{+}, \mathrm{Mg}^{2+}$, and $\mathrm{NO}_{3}{ }^{-}$contents have been found more than the Indian standards (BIS). The dissemination of ions in the qualitative analysis revealed the dominance order as $\mathrm{Ca}^{2+}>\mathrm{Na}^{+}>\mathrm{Mg}^{2+}>\mathrm{K}^{+}$and $\mathrm{HCO}_{3}{ }^{-}>\mathrm{SO}_{4}{ }^{2-}->\mathrm{Cl}^{-}>\mathrm{NO}_{3}{ }^{-}$. Using Piper's diagram, the groundwater types were found to be majorly $\mathrm{Ca}^{2+}-\mathrm{HCO}_{3}{ }^{-}$, $\mathrm{Ca}^{2+}-\mathrm{Na}^{+}-\mathrm{HCO}_{\overline{3}}, \mathrm{Ca}^{2+}-\mathrm{Mg}^{2+}-\mathrm{Cl}^{-}$and $\mathrm{Ca}^{2+}-\mathrm{Cl}^{-}$groups. From the Gibbs plot, it is observed that the samples fall between rock dominance and evaporation dominance zones. Based on irrigation indices such as permeability index, residual sodium carbonate, the groundwater is unsuitable for irrigation. In addition to that, water quality index values revealed that $49 \%$ of water samples are found unfit for drinking. Further, health risk assessment study carried out using United States Environmental Protection Agency (US EPA) guidelines showed that children are at higher health risk than men and women in the study region.
\end{abstract}

Keywords Upper Bhima Basin $\cdot$ Water quality index $\cdot$ Health risk assessment $\cdot$ Semiarid $\cdot$ Western India

Ajaykumar Kadam

kadamajaykumar1@gmail.com

Huzefa Shaikh

huzefa.sk99@gmail.com

Himanshu Gaikwad

himanshugaikwad23@gmail.com

Bhavana Umrikar

bnumrikar@gmail.com

1 Department of Geology, Savitribai Phule Pune University, Pune, Maharashtra, India

2 Department of Environmental Sciences, Savitribai Phule Pune University, Pune, Maharashtra, India

\section{Introduction}

Groundwater is the main source that caters the need of inhabitants from rural part for daily activities, especially in a developing country like India (Gaikwad et al. 2018; Kumar et al. 2020; Kate et al. 2020). All the agricultural practices carried out in the country are majorly dependent on this hidden natural resource (Srivastava and Parimal 2020; Marghade 2020; Verma et al. 2020). Specifically, in arid and semiarid provinces, subsurface water is mostly limited due to the scanty precipitation, high evaporation and surface runoff (Camacho Suarez et al. 2015; Kadam et al. 2020). While meeting the demands from various sectors, this precious resource is getting scarce, overexploited and contaminated in many parts of the country (Avvannavar and Shrihari 2008; Vasanthavigar et al. 2010; Sharma 
and Kansal 2011). Moreover, the ingestion of such polluted groundwater could upsurge the hazards of aquatic infection epidemic (Wu and Sun 2016; Li et al. 2019). The degrading groundwater quality has become a serious universal issue for sustainable development ( $\mathrm{Li}$ et al. 2019; Adimalla and $\mathrm{Wu}$ 2019). Hence, it is extremely important to understand the hydrogeochemical characteristics of groundwater for sustainable resource development and governance.

Various studies have been reported regarding the geochemistry of waters from semiarid region including the drinking and irrigation water suitability (Avvannavar and Shrihari 2008; Karyab et al. 2019; Mukate et al. 2019; Adimalla et al. 2020; Verma et al. 2020; Wagh et al. 2020), water quality index and health risk assessment ( $\mathrm{Li}$ et al. 2016; Kawo and Karuppannan 2018; Mgbenu and Egbueri 2019; Adimalla et al. 2019; Zhang et al. 2020). It has been observed that in most of the studies, groundwater quality is deteriorated because of the upsurge in water demand due to fast-growing inhabitants as well as industrial development. Adimalla et al. (2018) evaluated the groundwater quality in Peddavagu area from Central Telangana (PCT), South India, for fluoride enrichment by rock-water interaction. Quijano et al. (2017) assessed the risk of nitrates in the Region of Valencia (Spain) and found that the exposures to nitrate from vegetables are improbable. Mgbenu and Egbueri (2019) examined the hydrogeochemical signatures, computed water quality indices and assessed health risk in the region of southeast Nigeria. The assessment results showed that the variations in hydrogeochemical signatures and quality of waters are attributed to the collective effects of man-made actions and lithogenic processes such as silicate weathering and ionic exchanges. Bamousa and El Maghraby (2016) have carried out the groundwater characterization and quality assessment to identify the sources of pollution in Madinah, Saudi Arabia. Deshmukh (2013) studied the impact of man-made activities on the quality of groundwater from Sangamner Area, Ahmednagar District, Maharashtra, India. Chidambaram et al. (2011) attempted the hydrochemical assessment of coastal groundwater in Southern India for major ions with the emphasis on fitness of groundwater for drinking and agricultural purposes. However, Avvannavar and Shrihari (2008) evaluated water quality index for domestic purposes in Netravathi River basin from South India.

Subsequently, hydrogeochemical characterization of groundwater for domestic and irrigation purposes using water quality index and potential health risks assessment have been carried out by many researchers (Narsimha 2018; Zhang et al. 2018; Li et al. 2019; Adimalla 2020), as these are the most prevalent approaches to identify the groundwater suitability for different purposes. The studies carried out by various researchers (Panaskar et al. 2017; Mukate et al. 2018; Varade et al. 2018; Kadam et al. 2019a, b; Wagh et al. 2020) in Deccan Volcanic Province have shown that the natural factors such as geology, hydrodynamics and hydrogeomorphology along with man-made activities have brought major changes in chemical composition of groundwater. As the study region incorporates the rural areas, agriculture is the dominant source of income for the villagers. The source of groundwater for agriculture in this region is large-diameter dug wells, cost-efficient deep bore wells and in few places dug-cum-bore wells. In order to intensify the crop production, most common practices such as application of high amount of chemical fertilizers and pesticides are in vogue that leach downward and lead to contamination of water.

GIS is one of the most efficient techniques for evaluating the hydrogeochemical characteristics and the quality of groundwater, which has been implemented by many workers (Umrikar and Devi 2011; Wagh et al. 2019; Kadam et al. 2019a, b; Adimalla and Taloor 2020). Groundwater quality zonation map is helpful in identifying the contaminated locations of groundwater and also in indicating the potential hazardous zones that can assist various officials working in that region. In the present study, hydrogeochemical characterization of groundwater from semiarid region of western India is performed which assesses the suitability for domestic and agriculture purposes. Additionally, the groundwater suitability zones for domestics and agriculture purposes have been created using GIS technique. Finally, the health risk is assessed for children and adults (men and women) due to ingestion of water contaminated with high nitrate concentration. With the help of this study, improved observing plan of groundwater quality and preventive measures for susceptible zones would be implemented by administrative planners and decision-makers.

\section{Study area}

Upper Bhima Basin (Survey of India Toposheet No $47 \mathrm{~J} / 5$, $47 \mathrm{~J} / 6,47 \mathrm{~J} / 9$ and $47 \mathrm{~J} / 10$ ) area lies between $18^{\circ} 30^{\prime} 00^{\prime \prime}$ and $19^{\circ} 00^{\prime} \mathrm{N}$ latitudes and between $74^{\circ} 10^{\prime} 00^{\prime \prime}$ and $74^{\circ} 30^{\prime} 00^{\prime \prime}$ E longitudes (Fig. 1). The study area is comprised of four subwatersheds (BM-16, BM-27, BM-28 and BM-34) and is $810 \mathrm{~km}^{2}$ in extent.

The highest elevation in the area is $791 \mathrm{~m}$, and the lowest elevation is $425 \mathrm{~m}$ above the mean sea level. The area is about $70 \mathrm{~km}$ from Pune and is well accessible by road (Pune-Ahmednagar highway). The study area receives rainfall during early parts of June right up to the end of September that is very uncertain and erratic with an average annual of $497 \mathrm{~mm}$. The average maximum temperature is about $32{ }^{\circ} \mathrm{C}$ and minimum $21^{\circ} \mathrm{C}$. The highest temperature in the summer months of April and May goes up to $40{ }^{\circ} \mathrm{C}$ representing semiarid climate of Western India; hence, evaporation is the dominant process. 

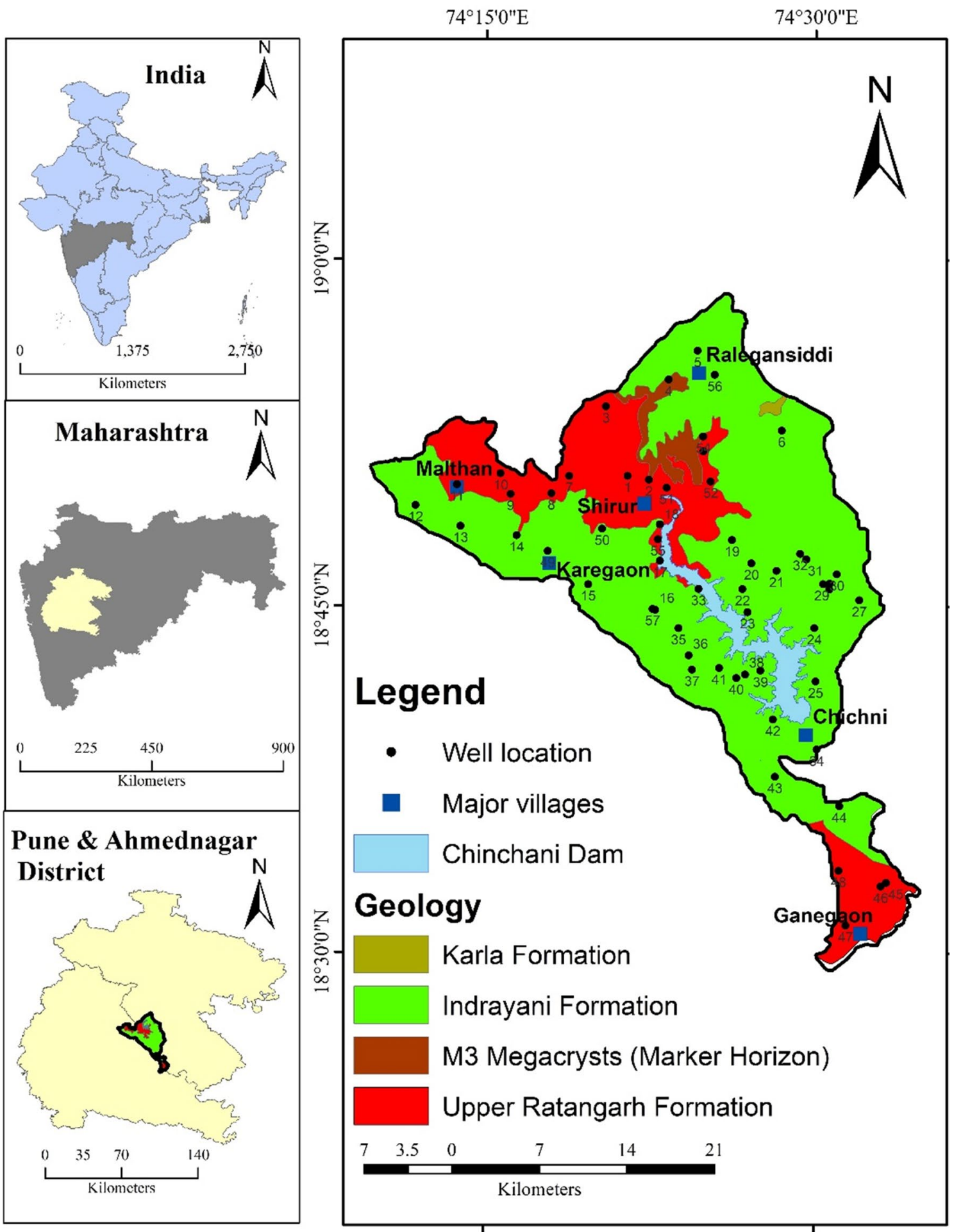

Fig. 1 Study area: Upper Bhima Basin

The Upper Bhima Basin area is covered by basalt flows of Cretaceous-Paleocene age with Quaternary alluvial and colluvio-alluvial deposits occurring in the valleys. The lava pile exposed in the area is made up of both compound pahoehoe flows and a`a flows and has been grouped into Ratangarh and Indrayani Formations of the Sahyadri Group of Deccan Trap Super Group. These formations are separated by marker horizons Megacryst M3 and Giravalli GPB (Godbole et al. 1996; Hooper et al. 1988). Megascopically, the flows are light to dark grey, fine to coarse grained, nonporphyritic 
to porphyritic. The porphyritic ones are mostly plagioclase phyric, with fine- to coarse-size phenocrysts exhibiting sparsely to moderately porphyritic texture. Jointing is common in the dense part of the flows. The pahoehoe flows exhibit fewer regular joints as compared to a a flows. They exhibit sheet joints towards the top which are clearly seen in the well sections cutting the pahoehoe flows. The a a flows are highly jointed, forming colonnade and entablature zones and more than one tiers. Fractures in the area generally trend NNW-SSE and NE-SW.

\section{Materials and methodology}

\section{Sampling and analytical procedures}

The hydrogeochemical assessment of groundwater for domestic and agricultural purposes, computing water quality index and potential health risks assessment from semiarid part of Western India were performed by collecting 57 groundwater samples from dug wells up to $18 \mathrm{~m}$ depth during post-monsoon (December 2018) season, while in premonsoon most of the dug wells get dry. The groundwater samples were collected in a bottle pre-washed with distilled water of 1 litre capacity and dried before fieldwork. The onfield measurements were done for $\mathrm{pH}$, electrical conductivity (EC) and total dissolved solids (TDS) by using Hanna HI 9811-5 handheld meter. Further, the groundwater samples were analysed for various hydrochemical parameters such as calcium $\left(\mathrm{Ca}^{2+}\right)$, magnesium $\left(\mathrm{Mg}^{2+}\right)$ and total hardness (TH) by using APHA standard method, while sodium $\left(\mathrm{Na}^{+}\right)$ and potassium $\left(\mathrm{K}^{+}\right)$were determined by flame photometer (Systronics Model 130) and major anions [chloride $\left(\mathrm{Cl}^{-}\right)$, bicarbonate $\left(\mathrm{HCO}_{3}{ }^{-}\right)$, sulphate $\left(\mathrm{SO}_{4}{ }^{2-}\right)$, nitrate $\left(\mathrm{NO}_{3}{ }^{-}\right)$and fluoride $\left(\mathrm{F}^{-}\right)$] were determined by high-pressure ion chromatography (HPIC).

The major ion concentrations in analysed samples were plotted on the Piper diagram using AquaChem software (AquaChem v4.0). The irrigation suitability indices such as sodium adsorption ratio (SAR), permeability index (PI), Kelly's ratio (KR), magnesium hazard (MH), sodium percentage $(\mathrm{Na} \%)$ and residual sodium carbonate (RSC) were calculated using the following formula (Table 1).

\section{Water quality index (WQI)}

Keeping in view the complaints of local people regarding dug well waters during the fieldwork, a water quality index (WQI) was determined to assess the groundwater suitability for drinking and domestic purposes (Horton 1965; Ramakrishnalah et al. 2009). Detailed facts and procedure about the WQI have been given by Asadollahfardi
Table 1 Irrigation suitability indices

\begin{tabular}{lll}
\hline Indices & Formula & Sources \\
\hline SAR & SAR $=\frac{\mathrm{Na}^{+}}{\left\{\frac{\mathrm{Ca}^{2+}+\mathrm{Mg}^{2+}}{2}\right\}^{0.5}}$ & Richards (1954) \\
PI & $\mathrm{PI}=\frac{\mathrm{Na}^{+}+\sqrt{\mathrm{HCO}_{3}^{-}}}{\left(\mathrm{Ca}^{2+}+\mathrm{Mg}^{2+}+\mathrm{Na}^{+}\right)} * 100$ & Doneen (1964) \\
KR & $\mathrm{KR}=\frac{\mathrm{Na}^{+}}{\mathrm{Ca}^{2+}+\mathrm{Mg}^{2+}}$ & Kelley (1963) \\
MH & $\mathrm{MH}=\frac{\mathrm{Mg}^{2+}}{\left(\mathrm{Ca}^{2+} * \mathrm{Mg}^{2+}\right)} * 100$ & Paliwal (1972) \\
$\mathrm{Na} \%$ & $\left.\mathrm{Na} \%=\frac{\mathrm{Na}^{+}+\mathrm{K}^{+}}{\left(\mathrm{Ca}^{2+}+\mathrm{Mg}^{2+}+\mathrm{Na}^{+}+\mathrm{K}^{+}\right)}\right) * 100$ & Wilcox (1948) \\
RSC & $\mathrm{RSC}=\left(\mathrm{CO}_{3}+\mathrm{HCO}_{3}\right)-(\mathrm{Ca}+\mathrm{Mg})$ & Eaton (1950a, b) \\
\hline
\end{tabular}

Here, all ion contents are expressed in meq/L

Table 2 Relative weight of chemical parameters

\begin{tabular}{llll}
\hline Sr. no. & $\begin{array}{l}\text { Chemical param- } \\
\text { eters }\end{array}$ & Weight $\left(w_{i}\right)$ & Relative weight \\
\hline 1 & $\mathrm{TDS}$ & 5 & 0.122 \\
2 & $\mathrm{pH}$ & 4 & 0.098 \\
3 & $\mathrm{TH}$ & 4 & 0.098 \\
4 & $\mathrm{HCO}_{3}^{-}$ & 1 & 0.024 \\
5 & $\mathrm{Cl}^{-}$ & 5 & 0.122 \\
6 & $\mathrm{SO}_{4}{ }^{2-}$ & 5 & 0.122 \\
7 & $\mathrm{NO}_{3}^{-}$ & 5 & 0.122 \\
8 & $\mathrm{Ca}^{2+}$ & 3 & 0.073 \\
9 & $\mathrm{Mg}^{2+}$ & 3 & 0.073 \\
10 & $\mathrm{Na}^{+}$ & 4 & 0.098 \\
11 & $\mathrm{~K}^{+}$ & 2 & 0.049 \\
& & $\sum w_{i}=41$ & $\sum W_{i}=1.00$ \\
\hline
\end{tabular}

(2015). Eleven parameters (TDS, $\mathrm{pH}, \mathrm{TH}, \mathrm{HCO}_{3}{ }^{-}, \mathrm{Na}^{+}$, $\mathrm{K}^{+}, \mathrm{Ca}^{2+}, \mathrm{Mg}^{2+}, \mathrm{Cl}^{-}, \mathrm{SO}_{4}{ }^{2-}$ and $\mathrm{NO}_{3}{ }^{-}$) were considered for the calculation of WQI values using Bureau of Indian Standards (BIS). Further, the suitable weights were allocated to each groundwater parameter. The parameters such as TDS, EC, $\mathrm{Cl}, \mathrm{SO}_{4}$ and $\mathrm{NO}_{3}{ }^{-}$were assigned higher weights of 5, whereas $\mathrm{HCO}_{3}$ was assigned lowest weights 1 depending on their importance in determination of water quality (Wagh et al. 2017; Adimalla et al. 2018; Kadam et al. 2019a, b). The relative weights (W3) (Table 2) were calculated for each parameter using Eq. (1). WQI values were calculated using Eqs. (2), (3) and (4)

$\mathrm{RW}_{i}=\mathrm{AW}_{i} / \sum \mathrm{AW}_{i}$

where $\mathrm{RW}_{i}$ is the relative weight, $\mathrm{AW}_{i}$ is the assigned weight and $n$ is the number of parameters.

The quality rating scale for each parameter is expressed with the following equation: 
$q_{i}=\left(c_{i} / s_{i}\right) \times 100$

where $q_{i}$ is quality rating for $i$ th parameter, $C_{i}$ is concentration of $i$ th chemical parameter of water sample $(\mathrm{mg} / \mathrm{l}), S_{i}$ is permissible standard for $i$ th parameter set by BIS.

Subindex $\left(\mathrm{SI}_{i}\right)$ for each parameter is calculated by following equation:

$\left(\mathrm{SI}_{i}=\mathrm{RW}_{i} \times q_{i}\right)$

where $\mathrm{SI}_{i}$ is subindex of $i$ th parameter, $q_{i}$ is rating based on the concentration of $i$ th parameter.

Finally, WQI is proposed using the following equation:

$\mathrm{WQI}=\sum \mathrm{SI}_{i}$

\section{Health risk assessment (HRA)}

To assess the potential human health risk due to ingesting of contaminated groundwater, the United States Environmental Protection Agency (US EPA 1989) developed a novel index that has been widely used (Narsimha and Rajitha 2018; Adimalla et al. 2019; Kadam et al. 2019a, b; Karande et al. 2020). There are many case studies reporting the problems of health risk due to consumption of contaminated water in India and all over the world (Karyab et al. 2019; Quijano et al. 2017; Li et al. 2016; Narsimha and Rajitha 2018; Adimalla et al. 2019; Karande et al. 2020). The health issues mainly arise from the contaminated air, water and soil surrounding the environment; hence, it is necessary to assess these resources and identify the sources of pollution. The present study area is mainly having the agricultural land use as major practices; therefore, elevated content of nitrate in dug well waters is a primary concern, where people are mostly reliant on the groundwater resources for domestic and agricultural purposes. Hence, the HRA was determined for $\mathrm{NO}_{3}{ }^{-}$by using the following equation:

$$
\text { Intake }_{\text {Oral }}=(\mathrm{Cw} \times \mathrm{IR} \times \mathrm{EF} \times \mathrm{ED}) /(\mathrm{BW} \times \mathrm{AT})
$$

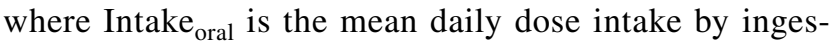
tion groundwater $[\mathrm{mg} / \mathrm{kg} / \mathrm{day}] ; \mathrm{Cw}$ is the content of a $\mathrm{NO}_{3}{ }^{-}(\mathrm{mg} / \mathrm{L})$ in the groundwater; IR shows the ingestion groundwater (L/day; $\mathrm{IR}=1.5 \mathrm{~L} /$ day for adults and $0.7 \mathrm{~L} /$ day children); EF represents the exposure frequency (days/ year; $\mathrm{EF}=365$ days/year); $\mathrm{ED}$ indicates the duration of exposure (years; $\mathrm{ED}=30$ years for adults and 12 years for children, obtained from the US 1989), BW is the average body weight in $\mathrm{kg}$ ( $\mathrm{BW}=65 \mathrm{~kg}$ and $55 \mathrm{~kg}$ for males and females, correspondingly, and $18.5 \mathrm{~kg}$ for children (ICMR 2009); and AT denotes the average time of exposure (days; $\mathrm{AT}=10,950$ days for adults and 4380 days for children).

Hazard quotient is calculated for the nitrate using Eq. (6)
$\mathrm{HQ}_{\text {oral }}=$ Intake $_{\text {oral }} / \mathrm{RfD}_{\text {oral }}$

where HQ is the hazard quotient and Rfd is the average reference dosage, respectively. For $\mathrm{NO}_{3}{ }^{-}$reference dose will be $1.6 \mathrm{mg} / \mathrm{kg} / \mathrm{day}$ according to United States Environmental Protection Agency (US EPA 2012). If the HQ value is greater than 1 and it is considered noncarcinogenic risk, while the safe limit for $\mathrm{HQ}_{\text {oral }}$ is equal to or less than 1 .

\section{GIS analysis}

The results obtained from analysis were used to prepare spatial variation maps. These maps were prepared using inverse distance-weighted interpolation tool in ArcGIS Software 10.4 (Adimalla et al. 2018). The results were assessed according to the drinking water quality standards suggested by Bureau of Indian Standards (BIS 2012). The base maps were prepared by the heads-up digitization using survey of India Toposheet, and district resources map was used to prepare the geology of area. The Garmin GPS points were imported in GIS environment to plot the dug well location map. The spatial variation map of parameters such as WQI, SAR, PI, KR, MH, Na\% and RSC was prepared. Spatial variation maps were prepared individually for male, female and children in accordance with HRA. Further, they were summed up using raster calculator tool in ArcGIS.

\section{Results and discussion}

\section{Hydrogeochemical characterization of groundwater}

In order to identify the point source of contamination in the groundwater, spatial distribution information is extremely useful. Most of the villages in India, especially those located in hilly areas, have groundwater as the only source for drinking and domestic requirements. Hence, the quality of groundwater is of utmost importance to secure the rural health. Thus, the suitability assessment of groundwater quality has become mandatory in the current scenario. The groundwater samples from the study area have been compared with BIS standards considering both permissible and desirable limits, and the data are presented in Table 3.

The $\mathrm{pH}$ of water is a function of host rock chemistry and its hydrological properties, as well as the rainfall, climate type and land use (Bartram and Ballance 1996). $\mathrm{pH}$ is vital parameter because it affects the biological and chemical properties of the groundwater. The BIS has prescribed a permissible range of $6.5-8.5$, and it is observed that the $\mathrm{pH}$ values in the groundwater samples range from 6.8 to 7.9 , i.e. well within the permissible limits. The EC ranges from 418 to $2987 \mu \mathrm{s} / \mathrm{cm}$ showcasing higher values due to the natural contents of salts as evapotranspiration surpasses 
Table 3 Descriptive statistics of physicochemical analysis of groundwater samples

\begin{tabular}{lrrrllll}
\hline Parameter $^{\mathrm{a}}$ & \multicolumn{1}{l}{ Min } & \multicolumn{1}{l}{ Max } & Average & $\begin{array}{l}\text { Maximum } \\
\text { desirable } \\
\text { limit } \\
\text { (MDL) }\end{array}$ & $\begin{array}{l}\text { Maximum } \\
\text { permissible } \\
\text { limit } \\
\text { (MPL) }\end{array}$ & $\begin{array}{l}\text { \% of sample } \\
\text { above MDL of sample }\end{array}$ & $\begin{array}{l}\text { \% } \\
\text { above MPL }\end{array}$ \\
\hline $\mathrm{pH}$ & 6.80 & 7.90 & 7.33 & $6.5-8.5$ & - & 0 & 0 \\
$\mathrm{EC}$ & 418.00 & 2987.00 & 1349.14 & - & - & - & - \\
$\mathrm{TDS}$ & 264.67 & 1916.81 & 857.39 & 500 & 2000 & 81 & 0 \\
$\mathrm{TH}$ & 186.00 & 960.00 & 486.62 & 300 & 600 & 61 & 21 \\
$\mathrm{Ca}^{2+}$ & 15.31 & 214.02 & 90.18 & 75 & 200 & 58 & 2 \\
$\mathrm{Mg}^{2+}$ & 9.16 & 126.70 & 58.34 & 30 & 100 & 84 & 2 \\
$\mathrm{Na}^{+}$ & 4.92 & 375.73 & 92.80 & 200 & - & 19 & - \\
$\mathrm{K}^{+}$ & 0.01 & 2.56 & 0.57 & 12 & - & 0 & - \\
$\mathrm{HCO}_{3}{ }^{-}$ & 125.00 & 490.00 & 272.29 & 200 & 600 & 81 & 0 \\
$\mathrm{SO}_{4}{ }^{2-}$ & 1.38 & 369.12 & 150.85 & 200 & 400 & 25 & 0 \\
$\mathrm{Cl}^{-}$ & 35.50 & 367.40 & 154.94 & 250 & 1000 & 21 & 0 \\
$\mathrm{NO}_{3}{ }^{-}$ & 0.33 & 108.23 & 32.56 & 45 & - & 26 & \\
$\mathrm{~F}^{-}$ & 0.02 & 0.91 & 0.55 & 1 & 1.5 & 0.00 & 0.00 \\
\hline
\end{tabular}

${ }^{\mathrm{a}}$ All values in $\mathrm{mg} / \mathrm{L}$ except $\mathrm{pH}$ and $\mathrm{EC}(\mu \mathrm{S} / \mathrm{cm})$ precipitation in a semiarid condition. TDS count is the sum of all ions that are dissolved in an aqueous state. TDS values range from 264.67 to $1916.81 \mathrm{mg} / \mathrm{L}$. The maximum desirable limit of BIS is $500 \mathrm{mg} / \mathrm{L}$ according to BIS samples found in the southern part which have TDS values higher than the permissible limit making it a hot spot. This area is in the proximity of dam having lower elevation experiencing intense agricultural practices, which are the major contributing factors to such high TDS content. The result of TDS shows that $81 \%$ of samples have higher TDS value than BIS desirable limit of $500 \mathrm{mg} / \mathrm{L}$, whereas all samples are below the BIS permissible limit of $2000 \mathrm{mg} / \mathrm{L}$ (Table 3). Hardness in the groundwater is a measure of total sum of calcium and magnesium ion concentrations. The $\mathrm{TH}$ values range between 186 and $960 \mathrm{mg} / \mathrm{L}$. About $61 \%$ of the samples have higher TH values than the desirable limit of $300 \mathrm{mg} / \mathrm{L}$ and $21 \%$ above the permissible limit of $600 \mathrm{mg} / \mathrm{L}$.

The calcium ion concentration in the groundwater ranges from 15.31 to $214.02 \mathrm{mg} / \mathrm{L}$. The average concentration of calcium ion is $90.18 \mathrm{mg} / \mathrm{L}$; it is well above as compared with BIS standard desirable limit of $75 \mathrm{mg} / \mathrm{L}$. The $\mathrm{Ca}^{2+}$ ion is the dominant cation of the study area. It is observed that $58 \%$ of the samples are above the desirable limit and only $2 \%$ of the samples are exceeding the permissible limits (Table 3). Higher values of calcium ion are found in the area where groundwater has higher residence time, which in turn results in high degree of rock-water interaction and $\mathrm{CaCO}_{3}$ is precipitated in water (Pawar et al. 2008). Magnesium and calcium have the similar behavioural characteristic in water but in general magnesium is different than that of calcium in their geochemical characteristics. Magnesium has smaller ions as compared to calcium (Hem 1985). Having the similar behavioural pattern, the concentration of magnesium is less due to less general abundance. Magnesium ion concentration in the Upper Bhima Basin ranges from 9.16 to $126.70 \mathrm{mg} / \mathrm{L}$. The permissible limit for magnesium is $100 \mathrm{mg} / \mathrm{L}$ (BIS), and only $2 \%$ of samples are found to be above the permissible limit. The groundwater of the study area is normally fit for consumption purpose with respect to magnesium. Main source of $\mathrm{Na}$ in the groundwater is weathering of rocks; however, higher values show that sodium ion also arises out of anthropogenic activities (Subbarao et al. 1996). Na concentration ranges from 4.92 to $375.73 \mathrm{mg} / \mathrm{L}$. The maximum desirable limit for sodium ion is $200 \mathrm{mg} / \mathrm{L}$ according to BIS standard showing 19\% samples are above the desirable limits. Normally, potassium ion concentration in natural water is less than sodium ion having the concentration less than $10 \mathrm{mg} / \mathrm{L}$ in the groundwater. The value for potassium ion varies from 0.01 to $2.56 \mathrm{mg} / \mathrm{L}$ as a result of weathering of host rocks and anthropogenic activities.

The dissemination of major ions analysed reveals the dominance as $\mathrm{HCO}_{3}{ }^{-}>\mathrm{SO}_{4}{ }^{2-}->\mathrm{Cl}^{-}>\mathrm{NO}_{3}{ }^{-}$hierarchical order in Upper Bhima Basin. Bicarbonate ion is one of the dominant anions and key source of alkalinity, and the subsidence from carbonate weathering processes and reaction of silicates with carbonic acid account for addition of $\mathrm{HCO}_{3}$ to groundwater (Chidambaram et al. 2011). The desirable limit of bicarbonate ion in drinkable water is $300 \mathrm{mg} / \mathrm{L}$ (WHO 2011). Analysis of groundwater samples shows that bicarbonate concentrations range from 129 to $490 \mathrm{mg} / \mathrm{L}$, and out of the total samples, $26 \%$ are above the desirable limit. High concentration of bicarbonate ion is found in most of the samples from the lower part of the study area showing decline in water table due to overexploitation of groundwater for 
irrigation purposes and water-rock interaction. Chloride is one of the most abundant anions which are found in almost all-natural groundwater resources in varying proportions as it has the property of being highly stable (Sawyer et al. 1978; Stites and Kraft 2001). However, feldspathoids such as sodalite, $\mathrm{Na}_{8}\left[\mathrm{Cl}_{2}\left(\mathrm{AlSiO}_{4}\right)_{6}\right]$ and the phosphate minerals such as apatite (Hem 1985) are some of the lithogenic sources occurring in igneous rocks. But in the present case, it seems highly unlikely, as the concentrations are tremendous for claiming the geogenic source. The $\mathrm{Cl}$ content in the groundwater ranges from 35.50 to $367.40 \mathrm{mg} / \mathrm{L}$ with the mean of 154.94 (Table 3). The study area has $21 \%$ samples above BIS desirable limit for drinking waters, and all samples were found to be beyond the permissible limits of BIS standards. At some places, $\mathrm{Cl}$ is high, because of anthropogenic activities, mainly sewage discharge from the populated area. The metallic sulphides are the major source of sulphate in the groundwater (Tiwari et al. 2013). In agricultural fields, around half to two-thirds of proportion of water is lost by evapotranspiration and the remaining amount infiltrates and joins the subsurface as a return flow. This infiltration of water into aquifers increases the salinity of groundwater (Vetrimurugan and Elango 2015). The significant concentration of $\mathrm{SO}_{4}^{2-}$ ion has been found in the regions that are highly irrigated, also anthropogenic stresses acting in the region. The sulphate content in the groundwater ranges from 1.68 to $369.12 \mathrm{mg} / \mathrm{L}$ with the average value of $150.58 \mathrm{mg} / \mathrm{L}$ (Table 3). Sulphate ion concentration in the study area is enhanced by the agricultural practices as the chemical fertilizers are used for augmenting the nutrient contents of soil. In the study area, $25 \%$ of the samples have concentration more than $200 \mathrm{mg} / \mathrm{L}$ (BIS standard), which shows that the groundwater in the area is significantly affected by manmade actions, which might be the resultant of local sewages and composts.

The emergence of nitrate ion in our subsurface natural resource completely relies upon the lightening experiences during pre-monsoon thunder showers, biological nitrogen fixation by microbes (e.g. Rhizobium bacteria) and nitrogenous fertilizers application during crop cultivation period after monsoon season. The water-soluble nitrate fertilizers (e.g. urea, ammonium sulphate) easily get accumulated into groundwater system, and excess of these result in serious nitrate pollution (Pawar and Shaikh 1995). The nitrate $\left(\mathrm{NO}_{3}{ }^{-}\right)$ion is the highest responded type of nitrogen in the atmosphere and is moderately nontoxic to amphibians (Vetrimurugan and Elango 2015). The high content of nitrate along with phosphate results in eutrophication as the main environmental problem. The $\mathrm{NO}_{3}$ in the study area ranges from 0.33 to $108.23 \mathrm{mg} / \mathrm{L}$ (Table 3 ). Actually, various studies have detected a high relationship among farming practices and nitrate content in subsurface and surface waters (Adimalla et al. 2018). The contamination of nitrate ions is not only found in India but also observed globally (Marghade 2020; Li et al. 2019; Karyab et al. 2019; Quijano et al. 2017; Majumdar and Gupta 2000). Many environmental scientists/workers have classified nitrate sources into a nonpoint type such as chemical fertilizers and point sources such as septic tanks and sewage systems (Narsimha and Sudarshan 2013; Adimalla 2020; Rao 2002). About 26\% of the samples are above the BIS desirable limit of $45 \mathrm{mg} / \mathrm{L}$. Classification of human health risk (Table 4) shows that the nitrate concentration in $26 \%$ and $2 \%$ of groundwater samples have high and very high risks, respectively. High nitrate concentration, above $45 \mathrm{mg} / \mathrm{L}$, can cause the methaemoglobinaemia development and gastric and/or oesophageal cancer to exposed inhabitants (Adimalla et al. 2019),

Fluoride is found at higher concentrations in the groundwater, especially in arid and semiarid areas in different geological environments in the world, where the countryside inhabitants grieve from fluorosis disease, since there are no sources of water for drinking. However, fluoride concentration ranges from 0.02 to $0.91 \mathrm{mg} / \mathrm{L}$, with a mean value of $0.56 \mathrm{mg} / \mathrm{L}$ (Table 3), and is found below the desirable limit (BIS 2012). About $25.71 \%$ of groundwater sampling locations presented risk for dental fluorosis, and $18.10 \%$ and $4.76 \%$ of samples indicated possibility for dental to skeletal fluorosis in the study region (Table 6).

\section{Groundwater types}

The groundwater types of the study area were determined based on its geochemical characteristics of major ions; Piper (1953) proposed an effective plot. This is helpful to know the total element character of waters in terms of cations and anions composition. Using Piper diagram (Fig. 2), groundwater of the study area is categorized into: (I) $\mathrm{Ca}^{2+}-\mathrm{HCO}_{3}{ }^{-}$, (II) mixed $\mathrm{Ca}^{2+}-\mathrm{Na}^{+}-\mathrm{HCO}_{3}{ }^{-}$, (III) mixed $\mathrm{Ca}^{2+}-\mathrm{Mg}^{2+}-\mathrm{Cl}^{-}$and (IV) $\mathrm{Ca}^{2+}-\mathrm{Cl}^{-}$types. From the Piper plot, it is evident that the groundwater is mainly constituted of calcium, magnesium and bicarbonates. Calcium and magnesium impart

Table 4 Nitrate and fluoride concentrations and health risk assessment

\begin{tabular}{llll}
\hline Elements health risk & $\begin{array}{l}\text { Concentra- } \\
\text { tion (mg/L) }\end{array}$ & $\begin{array}{l}\text { Number of } \\
\text { samples }\end{array}$ & $\%$ of samples \\
\hline Nitrate & $<45$ & 41 & 72 \\
$\quad$ No risk & $46-100$ & 15 & 26 \\
High risk & $>100$ & 1 & 2 \\
$\quad$ Very high risk & $<0.5$ & 29 & 51 \\
Fluoride & $0.6-1.5$ & 28 & 49 \\
$\quad \begin{array}{l}\text { Dental caries } \\
\text { Required levels for } \\
\quad \text { human health }\end{array}$ & $1.6-2$ & 0 & 0 \\
$\quad$ Dental fluorosis & & & \\
\hline
\end{tabular}


Fig. 2 Piper plot for groundwater samples showing water type from the study area

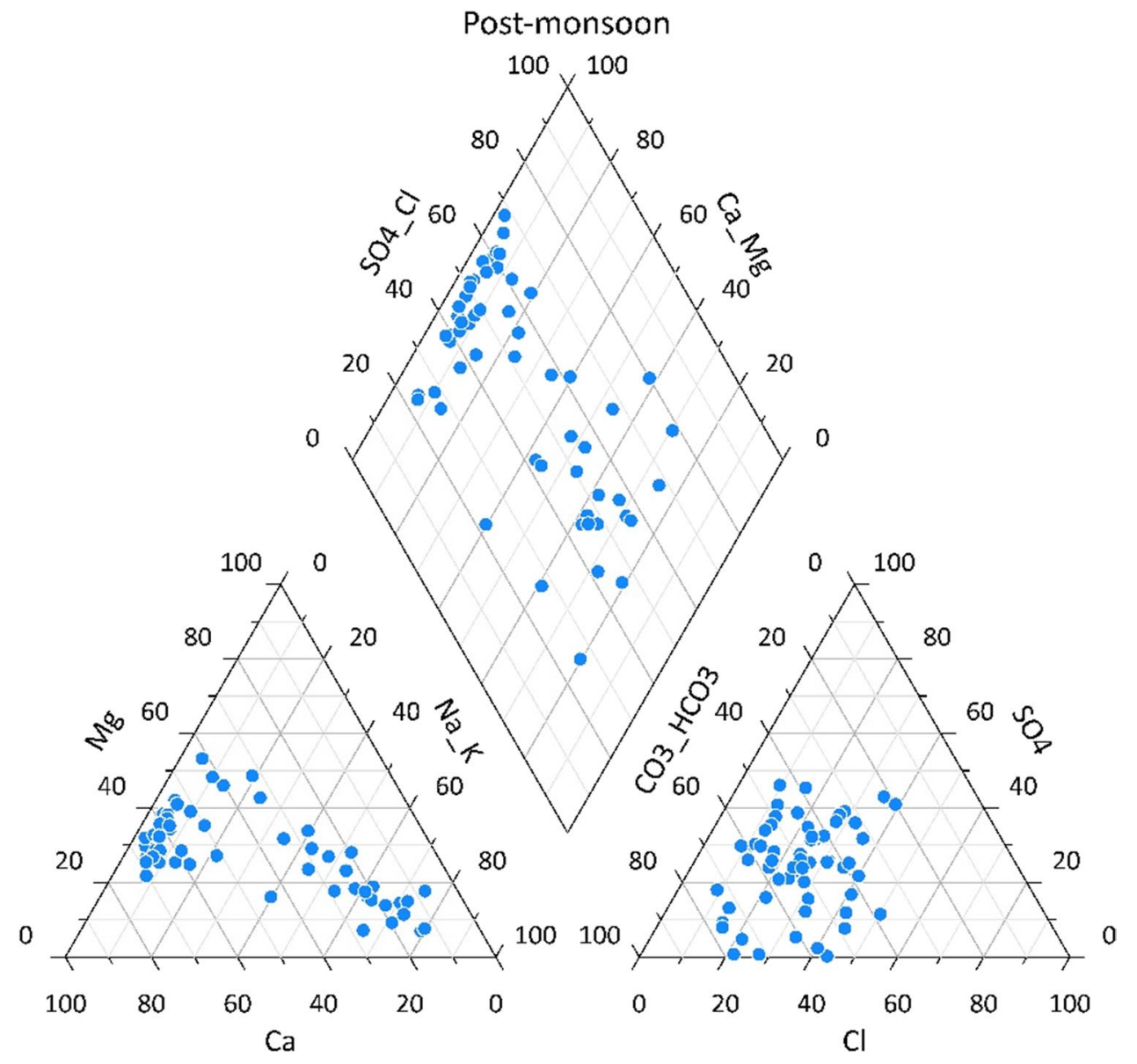

hardness to the rock and are found due to weathering processes which lead to dissolution of minerals from parent rock, i.e. basalts (Gaikwad et al. 2020). Bicarbonates, on the other hand, are dominant due to weathering of carbonates and dissolution of silicate minerals. Higher values are also indicative of the anthropogenic activities. According to Piper, there is not much dominance of sodium-chloride-sulphate in the groundwater samples.

\section{Gibbs diagram for geochemical evolution}

In geochemical evolution of groundwater, there are variegated proceedings involved. To understand the dominance of either precipitation, rock matter or evaporation process, Gibbs (1970) designed two semilog diagrams which are now known as the Gibbs diagrams, in which graphs of TDS versus $\mathrm{Cl}^{-} /\left(\mathrm{Cl}^{-}+\mathrm{HCO}_{3}{ }^{-}\right)$and TDS versus $\left(\mathrm{Na}^{+}+\mathrm{K}^{+}\right) /$ $\left(\mathrm{Na}^{+}+\mathrm{K}^{+}+\mathrm{Ca}^{2+}\right)$ for anions and cations are plotted, respectively (Fig. 3). From the plot, it is evident that the samples fall between rock dominance zone and evaporation dominance zone. As the general slope in the region is low, there is an increase in residence time of groundwater. This results in high rock-water interaction. As the groundwater is from semiarid climatic region, evaporation dominance is obvious.
Evidences of evaporation dominance have been observed in the well sections, where the walls were covered with calcrete formation. As a result of high residence time, rock-groundwater interaction is observed in these basaltic aquifers.

\section{Water quality index (WQI) for domestic suitability}

Quality of water is very significant to human because it has a direct link with human health and welfare. Based on the WQI values obtained, the categories are generated as very poor (200-300), poor (100-200), good (50-100) and excellent $(\leq 50)$. Out of the total of 57 samples, 27 are found very poor, one poor, 25 are good and only four are of excellent quality. Hence, it is inferred that $49 \%$ of water samples are found unfit for drinking. The spatial variation map (Fig. 4) shows that very poor quality is in the lower reaches of watershed, while rest of the area has poor to good water quality status.

\section{Irrigation water quality}

There should be a periodic check for quality of water that is used for crop growth. It helps to increase the crop yield and supports farming of superior crop varieties. With the 

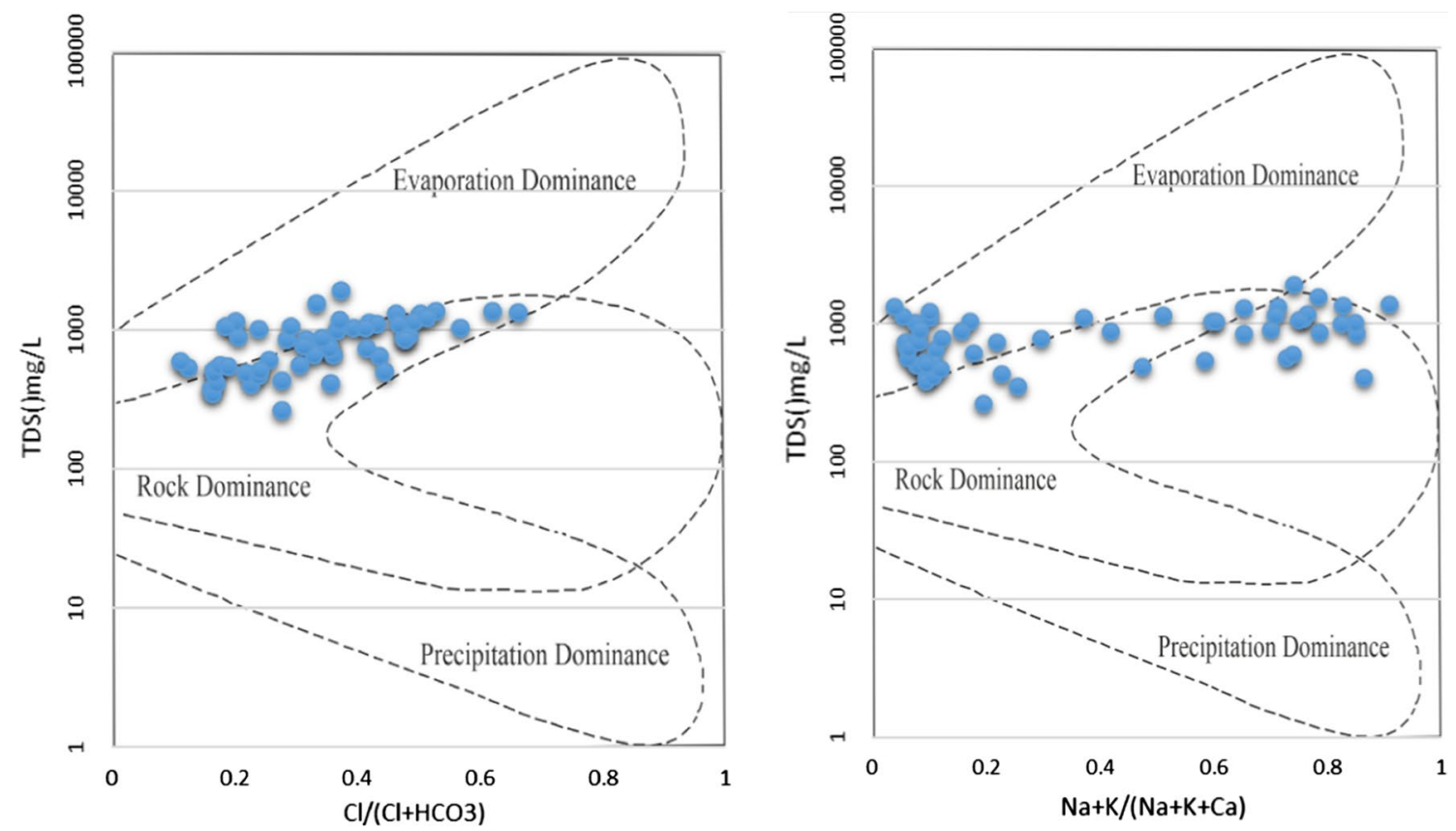

Fig. 3 Gibbs plot showing the groundwater of rock, precipitation and evaporation dominance

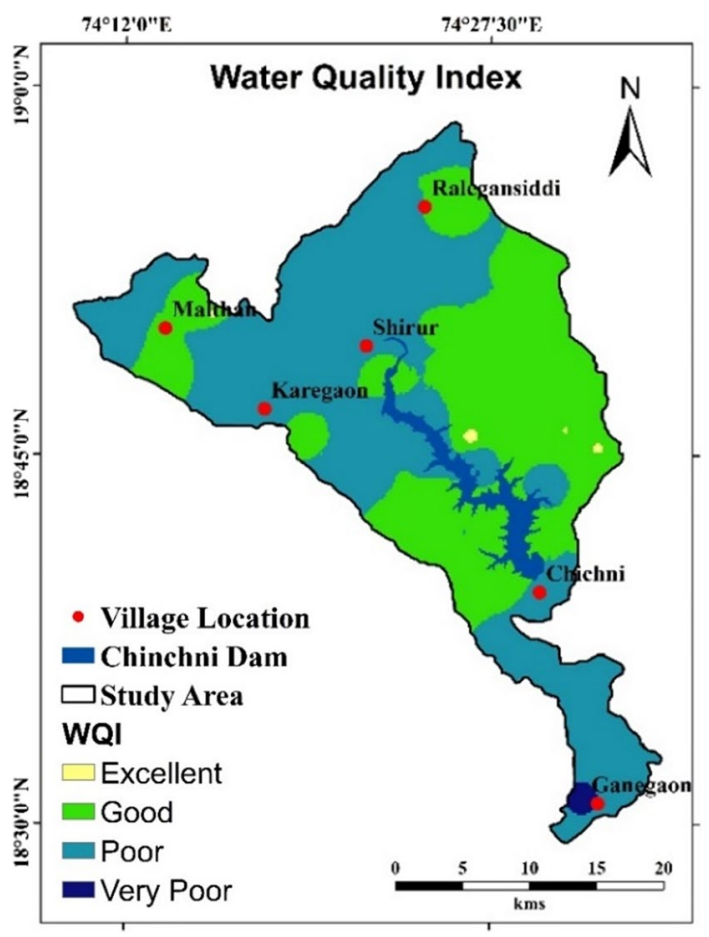

Fig. 4 Spatial variation in WQI

climate change, dependency on rainwater for farming is uncertain. Hence, the suitability assessment of groundwater for agriculture is important task from planning perspective. Essential parameters comprise numerous definite properties of water related to the quality and quantity of crops and conservation of soil efficiency. Therefore, the groundwater suitability indices were computed for irrigation. Suitability indices such as sodium adsorption ratio (SAR), permeability index (PI), Kelly's ratio (KR), magnesium hazard (MH), sodium percentage (\% $\mathrm{Na}$ ) and residual sodium carbonate (RSC) are discussed below:

\section{Sodium adsorption ratio (SAR)}

The sodium hazard is calculated by the absolute and relative concentration of cations in the groundwater and is termed as SAR (Richards 1954). The SAR value is the sodium content that exists in soil after absorption.

Higher values of SAR lead to high sodium concentration resulting in reduction in porosity of soils. The SAR values for most of the samples are found to be excellent, and those for few samples are unsuitable. About 58\% of samples were found to be excellent, $16 \%$ of samples were good, $5 \%$ of samples were doubtful and $21 \%$ of samples were unsuitable according to sodium hazard. Accordingly, it is inferred that $74 \%$ of samples had no salinity issue and $26 \%$ of samples had salinity; hence, some treatment is required before it can be used for agriculture purposes. But, if the SAR value surpasses 10, the groundwater can cause porousness problems in soil. The spatial variation in SAR values shows that northern part of the watershed covering Ralegan Siddhi village in Ahmednagar district, Shirur and Malthan major villages from Pune district has unsuitable to doubtful groundwater for irrigation (Table 5, Fig. 5). Majorly, the catchment part of dam is affected by high SAR values. 
Table 5 Irrigation groundwater quality indices values

\begin{tabular}{|c|c|c|c|c|}
\hline Parameter & Range & Water class & $\begin{array}{l}\text { No. of } \\
\text { sam- } \\
\text { ples }\end{array}$ & $\%$ of samples \\
\hline \multirow{4}{*}{$\begin{array}{l}\text { SAR (Richards } \\
\text { 1954) }\end{array}$} & $<10$ & Excellent & 33 & 58 \\
\hline & $10-18$ & Good & 9 & 16 \\
\hline & $18-26$ & Doubtful & 3 & 5 \\
\hline & $<26$ & Unsuitable & 12 & 21 \\
\hline \multirow[t]{3}{*}{ PI (Doneen 1964) } & $>75$ & Excellent & 6 & 11 \\
\hline & $75-25$ & Good & 24 & 42 \\
\hline & $>25$ & Unsuitable & 27 & 47 \\
\hline \multirow[t]{2}{*}{ KR (Kelley 1940) } & $<1$ & Suitable & 39 & 68 \\
\hline & $>1$ & Unsuitable & 18 & 32 \\
\hline \multirow{2}{*}{$\begin{array}{l}\text { MHR (Raghunath } \\
\text { 1987) }\end{array}$} & $<50$ & Suitable & 46 & 81 \\
\hline & $>50$ & Unsuitable & 11 & 19 \\
\hline \multirow{5}{*}{$\begin{array}{l}\text { \%NA (Wilcox } \\
\text { 1955) }\end{array}$} & $<20$ & Excellent & 31 & 54 \\
\hline & $20-40$ & Good & 5 & 9 \\
\hline & $40-60$ & Permissible & 7 & 12 \\
\hline & $60-80$ & Doubtful & 14 & 25 \\
\hline & $<80$ & Unsuitable & 0 & 0 \\
\hline \multirow{2}{*}{$\begin{array}{l}\% \mathrm{Na} \text { (Eaton 1950a, } \\
\text { b) }\end{array}$} & $<60$ & Safe & 43 & 75 \\
\hline & $>60$ & Unsafe & 14 & 25 \\
\hline \multirow{3}{*}{$\begin{array}{l}\text { RSC (Eaton 1950a, } \\
\text { b) }\end{array}$} & $<1.25$ & Good & 3 & 5 \\
\hline & $1.25-2.5$ & Doubtful & 0 & 0 \\
\hline & $>2.5$ & Unsuitable & 54 & 95 \\
\hline
\end{tabular}

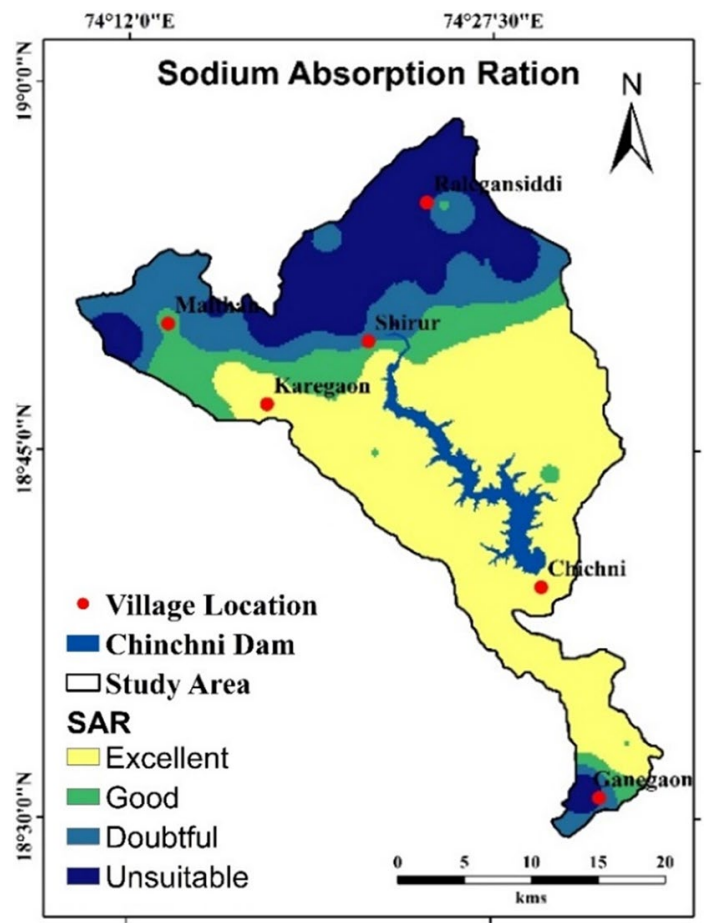

Fig. 5 Spatial variation in SAR

\section{Permeability index (PI)}

The suitability assessment can also be conducted by considering the permeability index method. The soil permeability is an important factor as it allows the infiltration of water in subsurface. The PI values are categorized as excellent, good and unsuitable based on the suitability of groundwater for the agricultural purposes. From the calculated PI values for all the water samples, it is observed that $11 \%$ fall under the class excellent, $42 \%$ class good and $47 \%$ class unsuitable. The spatial variation in PI in the groundwater of the area shows that Ralegan Siddhi village in Ahmednagar district reveals suitable water type (Table 5, Fig. 6). The unsuitable zones covering Chichani village are mainly present in lower reaches of watershed, mainly in command areas.

\section{Kelly's ratio (KR)}

$\mathrm{KR}$ is also another important parameter that can be used assess the quality of groundwater used in irrigation by considering sodium content present in the groundwater. As compared with SAR, it is not much advanced method for the detection of sodium content. It has only two simple classes, namely suitable and unsuitable. KR values above 1 are called as unsuitable, while those less than 1 are considered as suitable for irrigation purposes. Greater values show high concentration of sodium present. Kelly index values for the groundwater from 57 locations depict that $68 \%$ of samples

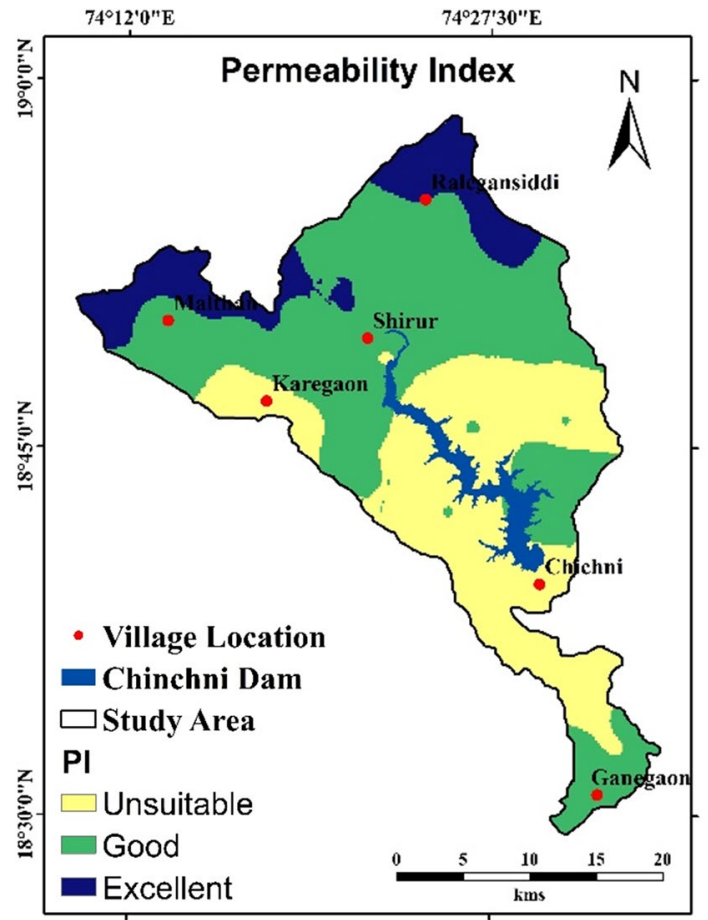

Fig. 6 Spatial variation in PI 
are suitable and $32 \%$ of samples are unsuitable for irrigation, suggesting their adversarial effects on agricultural activities. The spatial variation in KR in the groundwater of the area shows that Ralegan Siddhi village in Ahmednagar district and Shirur and Malthan major villages from Pune district have unsuitable water type for irrigation (Table 5, Fig. 7). According to the KR method, the groundwater from the upstream part of the study area is unsuitable for irrigation.

\section{Magnesium hazard (MH)}

Magnesium and calcium concentrations are in equilibrium in the groundwater and play a vital role in defining the quality type of groundwater. Elevated magnesium content has more adverse effects as compared to calcium on crop yield by converting the soil alkaline. Hence, it is extremely important to detect the amount of magnesium which is done with the help of magnesium hazard (MH) (Paliwal 1972). Based on this, the values obtained by calculation were grouped into two classes, suitable and unsuitable. Values less than 50 were considered as suitable, and values exceeding 50 were considered unsuitable. MH values for 57 samples depict $81 \%$ of samples are suitable and only $19 \%$ of samples are unsuitable for irrigation. The central part of the study area mainly shows unsuitable water type (Fig. 8). Higher occurrence of magnesium ion in agricultural waters decreases the soil fertility which changes it to alkaline and finally reduces crop yield.

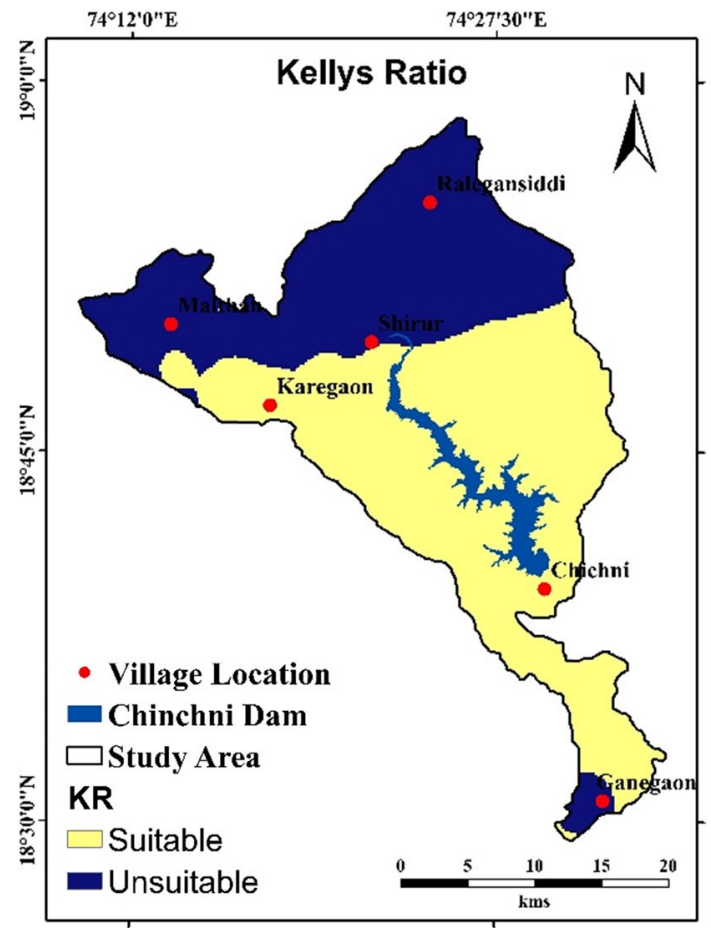

Fig. 7 Spatial variation in KR

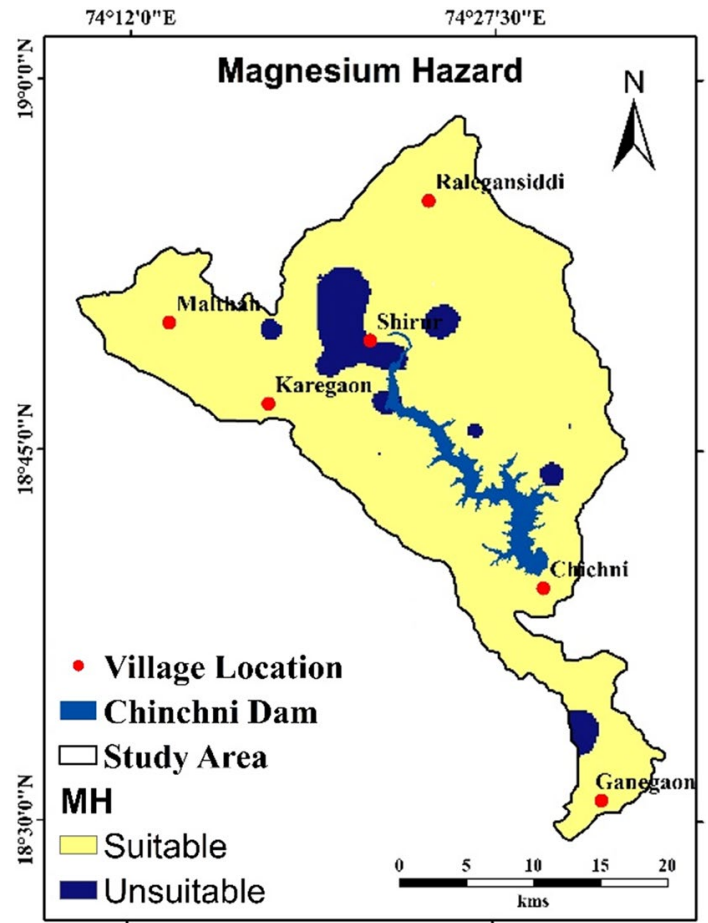

Fig. 8 Spatial variation in $\mathrm{MH}$

\section{Sodium percentage ( $\mathrm{Na} \%)$}

Sodium hazard in irrigation is calculated with the help of sodium percentage, thus being a very useful parameter. Sodium content has extremely adverse effects on soil. Na is the major content in soil and water because it has intense influence on soil penetrability and its structure (Rao 2002). Generally, Wilcox (1955) and Richards (1954) methods are used to understand the $\mathrm{Na} \%$. From the values calculated, 31 samples were excellent, five good, seven in permissible limits and 14 samples doubtful (Figs. 9, 10).

In Wilcox diagram (1955), the values of EC are plotted against $\mathrm{Na} \%$, and from this plot, it was inferred that the groundwater samples are observed in all the classes. According to the diagram, about $50 \%$ of samples fall in excellent-good-permissible class (Fig. 11).

There were a few sample locations which are permissible/ doubtful to doubtful and hence need proper treatment before use. The higher content of sodium ions in the groundwater is due to the long contact period with host rock resulting in dissolution of minerals and also the use of chemical fertilizers (Adimalla et al. 2018).

\section{Residual sodium carbonate (RSC)}

The hazardous effect of carbonates and bicarbonates was calculated with the help of residual sodium carbonate (RSC), detecting the attributes of groundwater for irrigation 


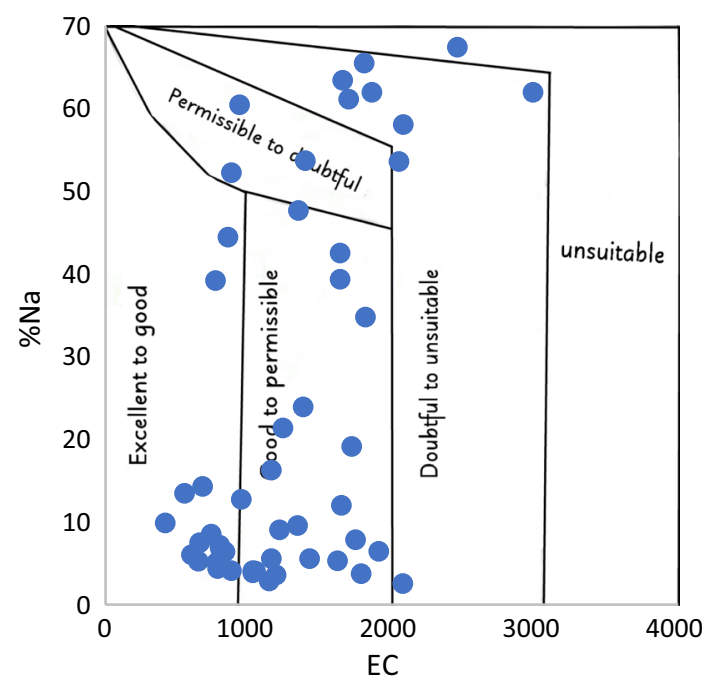

Fig. 9 Wilcox diagram of EC versus $\mathrm{Na} \%$

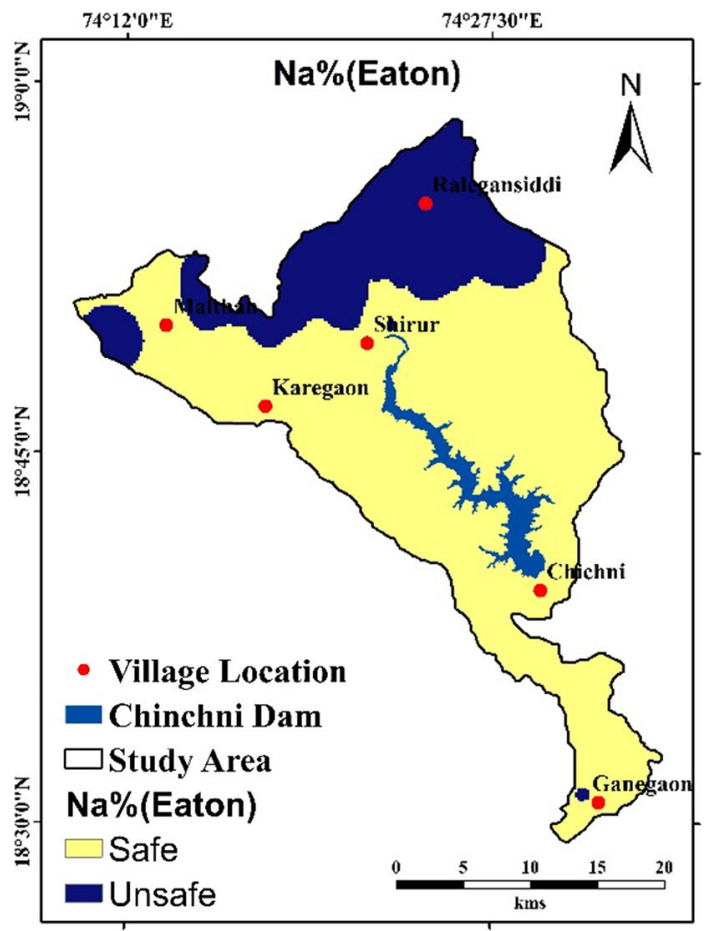

Fig. 10 Spatial variation in $\mathrm{Na} \%$ (Eaton method)

purposes. Particularly, the high amount of feeble acids such as carbonates and bicarbonates in the groundwater over the alkaline earths such as the total of calcium and magnesium alters the irrigating applicability of the groundwater. Eaton (1950a, b) concluded that increasing amount of RSC values in the groundwater increases SAR values, thus resulting in the soil becoming infertile due to such increasing concentration levels. Results show that only $5 \%$ of samples are

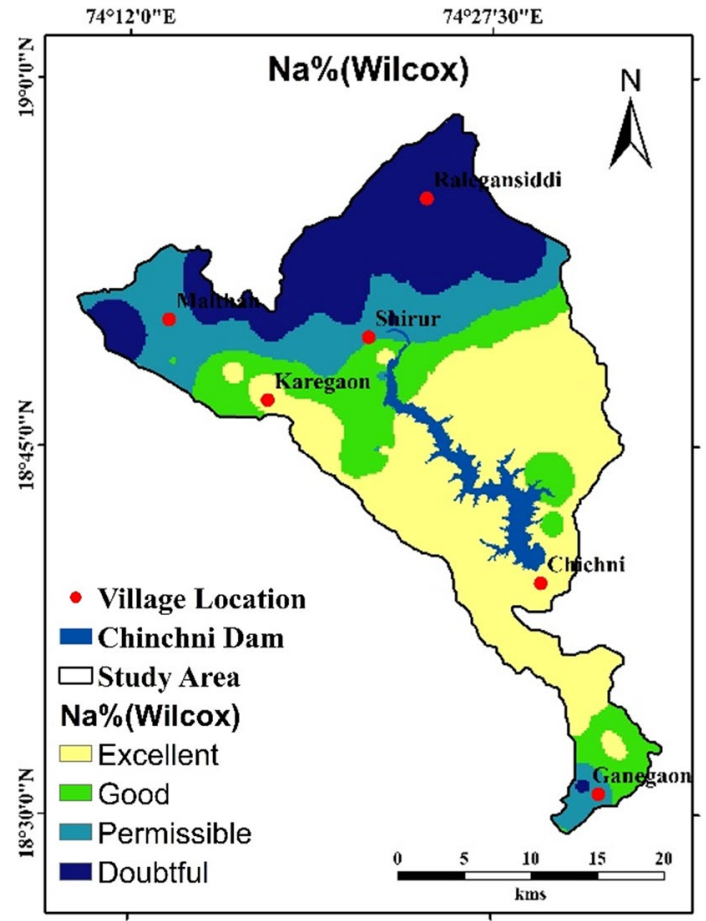

Fig. 11 Spatial variation in Na\% (Wilcox method)

suitable and $95 \%$ are unsuitable, which require some treatment before use. The constant use of groundwater having high RSC decreases the yield of crops (Ramesh and Elango 2012) (Fig. 12).

\section{Human health risk characterization}

Nitrate ion concentration in the groundwater used for drinking may pose an adverse health risk when the levels surpass the maximum permissible limit of $45 \mathrm{mg} / \mathrm{L}$ (BIS 2012). The noncarcinogenic risk due to nitrate ions in the groundwater is the cause of main worry for several nations (Quijano et al. 2017; Adimalla and Qian 2019a, b; Li et al. 2019; Karyab et al. 2019; Marghade 2020), particularly in India, where most of the inhabitants rely on groundwater for drinking and domestic purposes. Characteristically, the groundwater is mainly contaminated by nitrate ion and it poses a severe health risk as it breaks in the body into nitrite, which affects oxygen transmission by tie-up with haemoglobin and results in methaemoglobinaemia, which is particularly life threatening to infants and children (Majumdar and Gupta 2000; Fytianos and Christophoridis 2004; Gupta et al. 2011; Quijano et al. 2017; Karyab et al. 2019; Marghade 2020). Taking this fact into consideration, the US EPA has recommended a HRA method. Also, several scholars all over the world have used the US EPA method to evaluate the health risk for adults (men, and women) and children (Li et al. 2016; Quijano et al. 2017; Narsimha and Rajitha 2018; Adimalla et al. 2019; Karyab et al. 2019; Karande et al. 


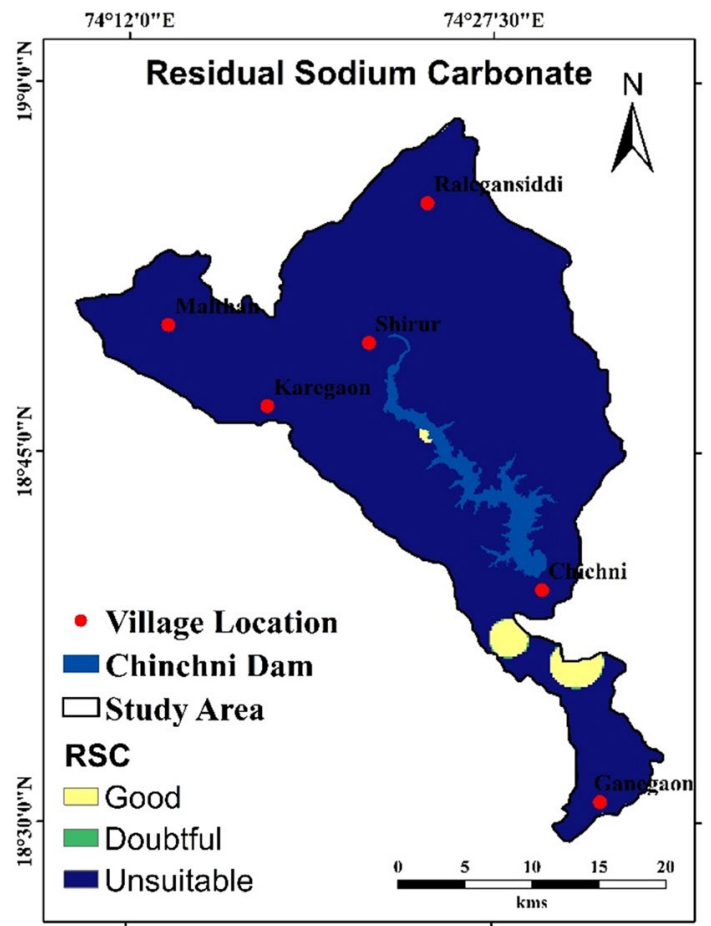

Fig. 12 Spatial variation in RSC

2020). Hence, in this study, human health risk of adults (men and women) and children due to elevated $\mathrm{NO}_{3}{ }^{-}$concentration in the groundwater has been predicted. Results of percentage of groundwater samples representing health risk to adults and children are presented in Table 6. The health risk assessment map was prepared for male, female and children separately in accordance with HRA analysis of above one and below one HRA value and reclassified. Further, they were summed up using raster calculator tool in ArcGIS. The spatial variation map of cumulative health risk assessment shows that in the lower reach part of study area, all contaminates get concentrated having higher risk (Fig. 13).

Most of the samples are found above 1 indicating high risk in adults as well as children in the study region. According to the integrated index, $33 \%$ of children are prone to high health risks, while the male and female are $9 \%$ and $16 \%$ (Table 6). Hence, from the risk assessment, children $\geq$ female $\geq$ male is in hierarchy of susceptibility to risks in the given study region. In India, there are maximum children that are suffering from various diseases such as dental fluorosis due to the consumption of contaminated groundwater.

\section{Conclusions}

The agriculture is a dominant occupation in the study area, and groundwater demand in future will be very high. Along with the concern on the availability of this natural resource,
Table 6 Percentage of groundwater samples representing health risk

\begin{tabular}{llcc}
\hline HI & Health risk & No of samples & \% of samples \\
\hline Male & & & \\
$<1$ & No risk & 52 & 91 \\
$>1$ & High risk & 5 & 9 \\
Female & & & \\
$<1$ & No risk & 48 & 84 \\
$>1$ & High risk & 9 & 16 \\
Children & & & \\
$<1$ & No risk & 38 & 67 \\
$>1$ & High risk & 19 & 33 \\
\hline
\end{tabular}

it becomes extremely important to monitor and maintain its compositional value for safeguarding human's health while maintaining the fertility of soil. This study is focussed on understanding the geochemistry of groundwater, its spatial variation and degree of pollution.

- From the analysis, it is observed that groundwater in this region is of neutral to alkaline type. Analysed physicochemical parameters indicate that few of the samples are within allowable limits of the BIS. Moreover, most of the parameters exceed the desirable limit at some sampled locations. Nitrate ion content exceeds the recommended limit of drinking in many groundwa-

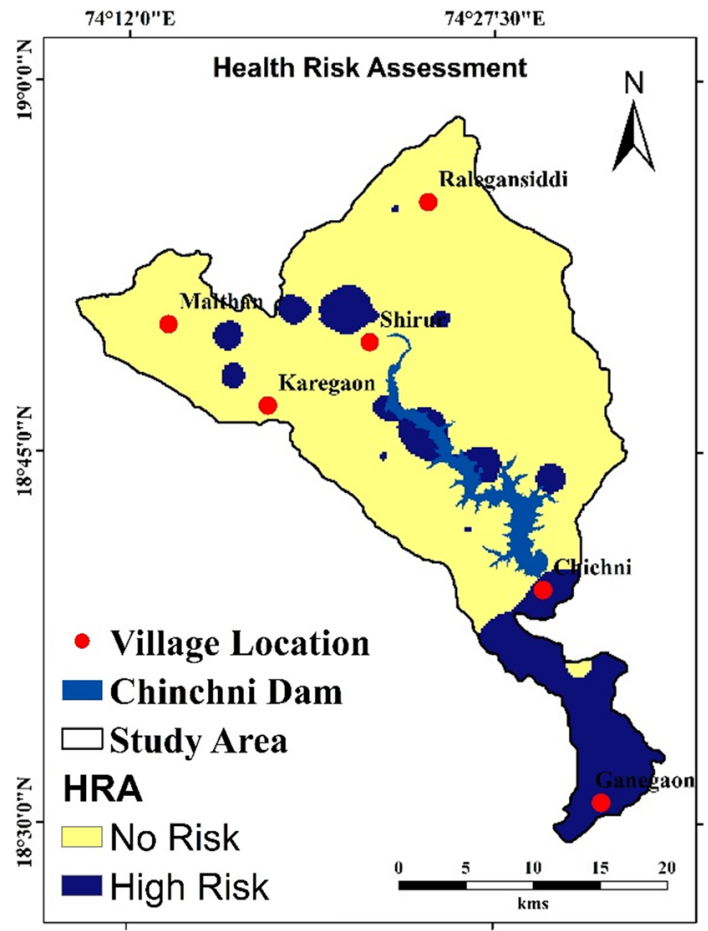

Fig. 13 Spatial variation in health risk assessment 
ter samples. A high content of TDS was observed due to accumulation of salt and anthropogenic inputs.

- Qualitative analysis shows that major cations have dominance of $\mathrm{Ca}^{2+}>\mathrm{Na}^{+}>\mathrm{Mg}^{2+}>\mathrm{K}^{+}$, and in major anions, it is $\mathrm{HCO}_{3}{ }^{-}>\mathrm{SO}_{4}{ }^{2-}->\mathrm{Cl}^{-}>\mathrm{NO}_{3}{ }^{-}$order. Alkaline earths $\left(\mathrm{Ca} 2+\right.$ and $\left.\mathrm{Mg}^{2+}\right)$ exceed the alkalis $\left(\mathrm{Na}^{+}\right.$and $\left.\mathrm{K}^{+}\right)$, and weak acids $\left(\mathrm{HCO}_{3}{ }^{-}-\right.$and $\left.\mathrm{CO}_{3}{ }^{2-}\right)$ exceed strong acids $\left(\mathrm{Cl}^{-}\right.$and $\left.\mathrm{SO}_{4}{ }^{2-}\right)$.

- From Piper's diagram, the groundwater facies identified in the region are (I) $\mathrm{Ca}^{2+}-\mathrm{HCO}_{3}{ }^{-}$, (II) mixed $\mathrm{Ca}^{2+}$ $\mathrm{Na}^{+}-\mathrm{HCO}_{3}{ }^{-}$, (III) mixed $\mathrm{Ca}^{2+}-\mathrm{Mg}^{2+}-\mathrm{Cl}^{-}$and (IV) $\mathrm{Ca}^{2+}-\mathrm{Cl}^{-}$, which represent host rock contribution and anthropogenic inputs. Gibbs plot shows that groundwater in this region is of rock dominance and evaporation dominance types. Calcium, magnesium, sodium and bicarbonates are found to be dominant in the groundwater samples. Calcium and magnesium impart hardness to the subsurface natural water resource that has geogenic source. Moreover, the sodium and bicarbonates are derived from anthropogenic activities.

- It was observed that in the study region, farmers apply low-grade fertilizers to enhance the crop productivity. Major cause of concern about these low-grade fertilizers is that they are rich in nitrate concentrations. The maximum permissible limit of nitrate in the groundwater is $45 \mathrm{mg} / \mathrm{L}$, and about $28 \%$ are exceeding this limit. These samples are located in the region of intense agricultural practices.

- Based on water quality index, it was inferred that $49 \%$ of water samples are found unfit and $51 \%$ are suitable for drinking. The irrigation indices values of PI and RSC depict that groundwater is unsuitable for irrigation, while SAR, MH, KR and \%Na show excellent and safe water quality.

- The study performed noncarcinogenic HRA considering the exposure of nitrate-contaminated drinking water in the rural region for men, women and children. The total noncarcinogenic risk ranged from 0.0048 to 1.56 for men, 0.0057-1.85 and 0.0079-2.56 for children and women, respectively. Thus, from the risk assessment, children $\geq$ female $\geq$ male is the order of decreasing susceptibility to health risks in the study region. The consumption of polluted groundwater is the main reason for the health risk, and thus the drinking water sources such as dug and bore well have to be monitored regularly to avoid the adversative effect on health. However, groundwater in some parts of the watershed is on the verge of getting polluted; hence, precautionary measures should be adopted in advance. In participatory groundwater movement, government officials, NGOs and farmers should come together and be educated to avoid any health complications arising due to water.

\section{Compliance with ethical standards}

Conflict of interest The authors declare that they have no conflict of interest.

Open Access This article is licensed under a Creative Commons Attribution 4.0 International License, which permits use, sharing, adaptation, distribution and reproduction in any medium or format, as long as you give appropriate credit to the original author(s) and the source, provide a link to the Creative Commons licence, and indicate if changes were made. The images or other third party material in this article are included in the article's Creative Commons licence, unless indicated otherwise in a credit line to the material. If material is not included in the article's Creative Commons licence and your intended use is not permitted by statutory regulation or exceeds the permitted use, you will need to obtain permission directly from the copyright holder. To view a copy of this licence, visit http://creativecommons.org/licenses/by/4.0/.

\section{References}

Adimalla N (2020) Spatial distribution, exposure, and potential health risk assessment from nitrate in drinking water from semi-arid region of South India. Hum Ecol Risk Assess 26(2):310-334. https://doi.org/10.1080/10807039.2018.1508329

Adimalla N, Qian H (2019a) Groundwater quality evaluation using water quality index (WQI) for drinking purposes and human health risk (HHR) assessment in an agricultural region of Nanganur, South India. Ecotoxicol Environ Saf 176:153-161. https:// doi.org/10.1016/j.ecoenv.2019.03.066

Adimalla N, Qian H (2019b) Spatial distribution and health risk assessment of fluoride contamination in groundwater of Telangana: a state-ofthe-art. Geochemistry. https://doi.org/10.1016/j.chemer.2019.125548

Adimalla N, Taloor AK (2020) Hydrogeochemical investigation of groundwater quality in the hard rock terrain of South India using Geographic Information System (GIS) and groundwater quality index (GWQI) techniques. Groundw Sustain Dev. https://doi. org/10.1016/j.gsd.2019.100288

Adimalla N, Wu J (2019) Groundwater quality and associated health risks in a semi-arid region of south India: implication to sustainable groundwater management. Hum Ecol Risk Assess 25(12):191-216. https://doi.org/10.1080/10807039.2018.1546550

Adimalla N, Vasa SK, Li P (2018) Evaluation of groundwater quality, Peddavagu in Central Telangana (PCT), South India: an insight of controlling factors of fluoride enrichment. Model Earth Syst Environ 4(2):841-852

Adimalla N, Qian H, Li P (2019) Entropy water quality index and probabilistic health risk assessment from geochemistry of groundwaters in hard rock terrain of Nanganur County, South India. Geochemistry. https://doi.org/10.1016/j.chemer.2019.125544

Adimalla N, Dhakate R, Kasarla A, Taloor AK (2020) Appraisal of groundwater quality for drinking and irrigation purposes in Central Telangana, India. Groundw Sustain Dev 10:100334

Asadollahfardi G (2015) Water quality indices (WQI). In: Water quality management. Springer, Berlin, Heidelberg, pp 21-39

Avvannavar SM, Shrihari S (2008) Evaluation of water quality index for drinking purposes for river Netravathi, Mangalore, South India. Environ Monit Assess 143(1-3):279-290

Bamousa AO, El Maghraby M (2016) Groundwater characterization and quality assessment, and sources of pollution in Madinah, Saudi Arabia. Arab J Geosci 9(8):536

Bartram J, Ballance R (eds) (1996) Water quality monitoring: a practical guide to the design and implementation of freshwater quality studies and monitoring programmes. CRC Press, Boca Raton 
BIS (2012) Indian standards specification for drinking water, BIS: 10500: 2012. http://www.cgwb.gov.in/Documents/WQ-stand ards.pdf

Camacho Suarez VV, Saraiva Okello AML, Wenninger JW, Uhlenbrook S (2015) Understanding runoff processes in a semi-arid environment through isotope and hydrochemical hydrograph separations. Hydrol Earth Syst Sci 19(10):4183-4199

Chidambaram S, Karmegam U, Prasanna MV, Sasidhar P, Vasanthavigar M (2011) A study on hydrochemical elucidation of coastal groundwater in and around Kalpakkam region, Southern India. Environ Earth Sci 64(5):1419-1431

Deshmukh KK (2013) Impact of human activities on the quality of groundwater from Sangamner Area, Ahmednagar District, Maharashtra, India. Int Res J Environ Sci 2(8):66-74

Doneen LD (1964) Notes on water quality in Agriculture Published as a Water Science and Engineering Paper 4001. Department of Water Science and Engineering, University of California

Eaton FM (1950a) Significance of carbonates in irrigation waters. Soil Sci 69(2):123-134

Eaton FM (1950b) Significance of carbonates in irrigation waters. Soil Sci 39:123-133

Fytianos K, Christophoridis C (2004) Nitrate, arsenic and chloride pollution of drinking water in Northern Greece. Elaboration by applying GIS. Environ Monit Assess 93(1-3):55-67

Gaikwad H, Shaikh H, Umrikar B (2018) Evaluation of groundwater quality for domestic and irrigation suitability from Upper Bhima Basin, Western India: a hydro-geochemical perspective. Hydrospatial Anal 2(2):113-123

Gaikwad S, Gaikwad S, Meshram D, Wagh V, Kandekar A, Kadam A (2020) Geochemical mobility of ions in groundwater from the tropical western coast of Maharashtra, India: implication to groundwater quality. Environ Dev Sustain 22(3):2591-2624

Gibbs RJ (1970) Mechanisms controlling world water chemistry. Science 170(3962): 1088-1090

Godbole SM, Rana RS, Natu SR (1996) Lava stratigraphy of Western Maharashtra. Gondwana Geol Mag Spl 2:125-135

Groundwater Quality in shallow aquifers in India, Central Groundwater Board 2018, p 191. http://cgwb.gov.in/WQ/Ground\%20Water\%20 Book-F.pdf

Gupta I, Salunkhe A, Rohra N, Kumar R (2011) Groundwater quality in Maharashtra, India: focus on nitrate pollution. J Environ Sci Eng 53(4):453-462

He S, Li P, Wu J, Elumalai V, Adimalla N (2019) Groundwater quality under land use/land cover changes: a temporal study from 2005 to 2015 in Xi'an, Northwest China. Hum Ecol Risk Assess Int J. https://doi.org/10.1080/10807039.2019.1684186

Hem JD (1985) Study and interpretation of the chemical characteristics of natural waters. U. S. Geology Survey, Water Supply Paper No. 2254

Hooper PR, Subbarao KV, Beane JE (1988) The giant plagioclase basalts (GPB) of western ghats, Deccan Traps. Mem Geol Soc Ind 10:135-140

Horton RK (1965) An index number system for rating water quality. $\mathbf{J}$ Water Pollut Control Fed 37(3):300-306

http://global.chinadaily.com.cn/a/201904/03/WS5ca407fea310484226 0b415d.html

ICMR G (2009) Physical development of Indian infants and children, vol 18. Technical Report Series

Kadam AK, Wagh VM, Muley AA, Umrikar BN, Sankhua RN (2019a) Prediction of water quality index using artificial neural network and multiple linear regression modelling approach in Shivganga River basin, India. Model Earth Syst Environ 5(3):951-962

Kadam A, Wagh V, Umrikar B, Sankhua R (2019) An implication of boron and fluoride contamination and its exposure risk in groundwater resources in semi-arid region, Western India. Environ Dev Sustain. https://doi.org/10.1007/s10668-019-00527-w
Kadam AK, Umrikar BN, Sankhua RN (2020) Assessment of recharge potential zones for groundwater development and management using geospatial and MCDA technologies in semiarid region of Western India. SN Appl Sci 2(2):312

Karande UB, Kadam A, Umrikar BN et al (2020) Environmental modelling of soil quality, heavy-metal enrichment and human health risk in sub-urbanized semiarid watershed of western India. Model Earth Syst Environ 6:545-556. https://doi. org/10.1007/s40808-019-00701-z

Karyab H, Hajimirmohammad-Ali R, Bahojb A (2019) A lumpedparameter model for investigation of nitrate concentration in drinking water in arid and semi-arid climates and health risk assessment. J Environ Health Sci Eng 17(1):457-465

Kate S, Kumbhar S, Jamale P (2020) Water quality analysis of UrunIslampur City, Maharashtra, India. Appl Water Sci 10(4):1-8

Kawo NS, Karuppannan S (2018) Groundwater quality assessment using water quality index and GIS technique in Modjo River Basin, central Ethiopia. J Afr Earth Sci 147:300-311

Kelley WP (1963) Use of saline irrigation water. Soil Sci 95:355-391

Kelley WP (1940) Permissible composition and concentration of irrigation water. In: Proceedings of the American society of civil engineers, vol 66, pp 607-613

Kumar VA, Mondal NC, Ahmed S (2020) Identification of groundwater potential zones using RS, GIS and AHP techniques: a case study in a part of Deccan Volcanic Province (DVP), Maharashtra, India. J Indian Soc Remote Sens 48:497-511. https://doi. org/10.1007/s12524-019-01086-3

Li F, Zhang J, Huang J, Huang D, Yang J, Song Y, Zeng G (2016) Heavy metals in road dust from Xiandao District, Changsha City, China: characteristics, health risk assessment, and integrated source identification. Environ Sci Pollut Res 23(13): 13100-13113

Li P, He X, Guo W (2019) Spatial groundwater quality and potential health risks due to nitrate ingestion through drinking water: a case study in Yan'an City on the Loess Plateau of northwest China. Hum Ecol Risk Assess Int J 25(1-2):11-31

Majumdar D, Gupta N (2000) Nitrate pollution of groundwater and associated human health disorders. Indian J Environ Health 42(1):28-39

Marghade D (2020) Detailed geochemical assessment \& indexing of shallow groundwater resources in metropolitan city of Nagpur (western Maharashtra, India) with potential health risk assessment of nitrate enriched groundwater for sustainable development. Geochemistry. https://doi.org/10.1016/j.cheme r.2020.125627

Mgbenu CN, Egbueri JC (2019) The hydrogeochemical signatures, quality indices and health risk assessment of water resources in Umunya district, southeast Nigeria. Appl Water Sci 9(1):22

Mukate S, Panaskar D, Wagh V, Muley A, Jangam C, Pawar R (2018) Impact of anthropogenic inputs on water quality in Chincholi industrial area of Solapur, Maharashtra, India. Groundw Sustain Dev 7:359-371

Mukate S, Wagh V, Panaskar D, Jacobs JA, Sawant A (2019) Development of new integrated water quality index (IWQI) model to evaluate the drinking suitability of water. Ecol Ind 101:348-354

Narsimha A (2018) Elevated fluoride concentration levels in rural villages of Siddipet, Telangana State, South India. Data Brief 16:693

Narsimha A, Rajitha S (2018) Spatial distribution and seasonal variation in fluoride enrichment in groundwater and its associated human health risk assessment in Telangana State, South India. Hum Ecol Risk Assess Int J 24(8):2119-2132

Narsimha A, Sudarshan V (2013) Hydrogeochemistry of groundwater in Basara area, Adilabad District, Andhra Pradesh, India. J Appl Geochem 15(2):224-237 
Paliwal KV (1972) Irrigation with saline water, Monogram no. 2 (New series). IARI, New Delhi

Panaskar DB, Wagh VM, Pawar RS (2017) Geochemical characterisation of fluoride containing groundwater from Sita Nadi Watershed, Bhokar Taluka, Maharashtra, India. J Earth Environ Sci (JEES) 145:10

Pawar NA, Shaikh IJ (1995) Nitrate pollution of ground waters from shallow basaltic aquifers, Deccan Trap Hydrologic Province, India. Environ Geol 25(3):197-204

Pawar NJ, Pawar JB, Kumar S, Supekar A (2008) Geochemical eccentricity of ground water allied to weathering of basalts from the Deccan Volcanic Province, India: insinuation on $\mathrm{CO}_{2}$ consumption. Aquat Geochem 14(1):41-71

Piper AM (1953) A graphic representation in the geochemical interpretation of groundwater analyses. Am Geophys Union Trans USA 25:914-923

Quijano L, Yusà V, Font G, McAllister C, Torres C, Pardo O (2017) Risk assessment and monitoring programme of nitrates through vegetables in the Region of Valencia (Spain). Food Chem Toxicol 100:42-49

Raghunath HM (1987) Groundwater. New Age International (P) Ltd. Publishers, Bengaluru

Ramakrishnalah CR, Sadashivalah C, Ranganna G (2009) Assessment of water quality index for the groundwater in Tumkur Taluk, Karnataka State, India. EJ Chem 6(2):523-530

Ramesh K, Elango L (2012) Groundwater quality and its suitability for domestic and agricultural use in Tondiar river basin, Tamil Nadu, India. Environ Monit Assess 184(6):3887-3899

Rao NS (2002) Geochemistry of groundwater in parts of Guntur district, Andhra Pradesh, India. Environ Geol 41(5):552-562

Richards LA (1954) Diagnosis and improvement of saline and alkali soils. LWW 78(2):154

Sawyer CN, McCarty PL, Parkin GF (1978) Chemistry for environmental engineers. Environ Manag 3:532

Sharma D, Kansal A (2011) Water quality analysis of River Yamuna using water quality index in the national capital territory, India (2000-2009). Appl Water Sci 1(3-4):147-157

Srivastava AK, Parimal PS (2020) Source rock weathering and groundwater suitability for irrigation in Purna alluvial basin, Maharashtra, central India. J Earth Syst Sci 129(1):52

Stites W, Kraft GJ (2001) Nitrate and chloride loading to groundwater from an irrigated north-central US sand-plain vegetable field. J Environ Qual 30(4):1176-1184

Subbarao C, Subbarao NV, Chandu SN (1996) Characterization of groundwater contamination using factor analysis. Environ Geol 28(4): 175-180

Tiwari RN, Mishra S, Pandey P (2013) Study of major and trace elements in groundwater of Birsinghpur Area, Satna District Madhya Pradesh, India. Int J Water Resour Environ Eng 5(7):380-386

Umrikar BN, Devi NM (2011) Groundwater quality assessment for Guhagar coastal area, Maharashtra, India. J Environ Res Dev 5(4):880-891

US EPA (2012) Our nation's air—status and trends through 2010. US EPA
US EPA (1989) Risk assessment guidance for superfund, volume 1: human health evaluation manual (part A) ((EPA/540/1-89/002: interim final). Office of Emergency and Remedial Response, Washington DC

Varade AM, Yenkie RO, Shende RR, Golekar RB, Wagh VM, Khandare HW (2018) Assessment of water quality for the groundwater resources of urbanized part of the Nagpur District, Maharashtra (India). Am J Water Resour 6(3):89-111

Vasanthavigar M, Srinivasamoorthy K, Vijayaragavan K, Ganthi RR, Chidambaram S, Anandhan P, Manivannan R, Vasudevan S (2010) Application of water quality index for groundwater quality assessment: Thirumanimuttar sub-basin, Tamilnadu, India. Environ Monit Assess 171(1-4):595-609

Verma A, Yadav BK, Singh NB (2020) Hydrochemical monitoring of groundwater quality for drinking and irrigation use in Rapti Basin. SN Appl Sci 2(3):1-15

Vetrimurugan E, Elango L (2015) Groundwater chemistry and quality in an intensively cultivated river delta. Water Qual Expo Health 7(2):125-141

Wagh VM, Panaskar DB, Muley AA et al (2017) Groundwater suitability evaluation by CCME WQI model for Kadava River Basin, Nashik, Maharashtra, India. Model Earth Syst Environ 3:557-565. https://doi.org/10.1007/s40808-017-0316-x

Wagh VM, Panaskar DB, Jacobs JA, Mukate SV, Muley AA, Kadam AK (2019) Influence of hydro-geochemical processes on groundwater quality through geostatistical techniques in Kadava River basin, Western India. Arab J Geosci 12(1):7

Wagh V, Mukate S, Muley A, Kadam A, Panaskar D, Varade A (2020) Study of groundwater contamination and drinking suitability in basaltic terrain of Maharashtra, India through PIG and multivariate statistical techniques. J Water Supply Res Technol AQUA 69:398-414

Wilcox LV (1948) The quality of water for irrigation use. US Department of Agriculture, Technical Bulletin 1962, Washington DC, USA

Wilcox LV (1955) Classification and use of irrigation waters. U S Department of Agriculture, New York

World Health Organization (WHO) (2011) Guidelines for drinking water quality, 4th edn. World Health Organization, Geneva

Wu J, Sun Z (2016) Evaluation of shallow groundwater contamination and associated human health risk in an alluvial plain impacted by agricultural and industrial activities, mid-west China. Expo Health 8:311-329

Zhang Y, Wu J, Xu B (2018) Human health risk assessment of groundwater nitrogen pollution in Jinghui canal irrigation area of the loess region, northwest China. Environ Earth Sci 77(7):273

Zhang Q, Xu P, Qian H (2020) Groundwater quality assessment using improved Water Quality Index (WQI) and Human Health Risk (HHR) evaluation in a semi-arid region of Northwest China. Expo Health. https://doi.org/10.1007/s12403-020-00345-w

Publisher's Note Springer Nature remains neutral with regard to jurisdictional claims in published maps and institutional affiliations. 